\title{
The Other Transformed: Orientalist Discourse in Book IV of Keats Endymion
}

\author{
Hossein Pirnajmuddin \\ English Department, University of Isfahan, Isfahan, Iran \\ Parisa Shiran \\ English Department, University of Isfahan, Isfahan, Iran
}

\begin{abstract}
As a Romantic orientalist text, book IV of Keats's Endymion is a "semi-mythical construct". This paper is an attempt to examine the cultural pressure of what Edward Said has called "orientalist discourse" on Keats, a marginal figure during his lifetime. The focus will be on the "Janus-faced ambivalence", in Homi K. Bhabha's terms, characteristic of the margins of a nation's space. Written in the post-Waterlooian period, Endymion is an archetypal quest for identity and self-recognition. The other is represented in the figure of the sorrowful Indian maid who is both the feminine and the oriental Other for the English masculine Self. Associated with exotic beauty, subjected to the "oriental scrutiny" and masculine gaze, the Indian maid is transformed and possessed to confirm the poet's masculine self. However, it is argued, issues such as mythologically significant figures, unheimlich images in the poetic space, orientalist assumptions, digressive passages, vacillating tone of the poem, partial cancelation of the recognized selves, control of the point of view, aestheticizing and spiritualizing of the love for the Indian maid and finally the dreamy quality of the poem complicate the issue of orientalism in the poem. Surveying such complexities, the study seeks to account for what has usually been considered poetic immaturity in Keats's Endymion. It is suggested that the artistic drawbacks of the poem are in part the result of the disturbing presence of an oriental Other figuring as a surrogate for a love Keats felt he could not have.
\end{abstract}

Index Terms - John Keats, Endymion, Orientalist Discourse, ambivalence, Self /Other, unheimlich, gaze

In "On Effeminacy of Character" William Hazlitt refers to "Keats's poetry as the primary example" of "corresponding literary style" of an effeminate nature (Mellor, 2001, p. 214). Keats' obsession with romance and his challenging "the existence of fixed, stable boundaries between the sexes" (Mellor, 2001, p. 215) are just two, among many, reasons for his association with female poetry. Instances of female figures abound in his poetry: Psyche, the Grecian "unravish'd bride of quietness," (“Urn”, 1) Madeline, a line of goddesses and even the racially Other Lamia. Keats "was named, moreover, not so much as Other and adversarial but as 'nothing', the dissociated figure of an allegory" (Levinson, 1988, p. 287). The quest pattern of romances, associated with wish-fulfillment, could easily provide the possibility of seeking identity. Unconsciously anxious about romance-writing, therefore, Keats developed an ambivalent stance towards gender. He "labors to establish a distance between the male poet and the female object of desire, a space where the poet can preserve a recognizable masculinity" (Mellor, 2001, p. 220-221). One such attempt at identity-recognition is his early Endymion in which Endymion figures as the "image of the poet"(Swann, 2001, p. 21). Keats's letters also, as Wassil (2000) observes, "take for their topic identity and split this identity into many parts and move it around the world through an imperial space echoing one of Keats's wishes that 'Endymion' be read in the 'wilds of america' [sic] and the 'plains of Egypt'" (p. 421).

The 'other', in the culminating book of the poem, in the figure of the sorrowful Indian maid, is both the feminine and the oriental. Wassil (2000) further notes that

"a poetry like Keats's, readily admitted to be involved with alienated production techniques and also participating in a major cultural displacement outward into empire and encounters with otherness, might be examined as a possible commentary on otherness, a sometimes willed and sometimes determined extension of a perspective on a condition which is equally complex, at times structured and unstructured" (p. 422).

According to Edward Said (1978), "nearly every nineteenth century writer [...] was extraordinarily aware of the fact of empire" (p. 14). Orientalism, in one sense, is defined as the thought of any "common" person about the Orient (Said, 1978, p. 69). "Though acknowledged," orientalism "is not seen as dominating the poetry or informing the poetics of Keats, a lack of emphasis that may be due to a later effect of an earlier marginalization of a 'political' Keats (Wassil, 2000, p. 419).

Endymion, as Keats says, is "written to please myself and in hope to please others, and for a love of fame" (1818, p. 73). Written with such hope, the poem shows the cultural pressure of "orientalist discourse" in representing England's Orient-as-India. As Butler (1994) points out, Romantic "poems on East," are "commonly allegories of empire and generally located where real-life empires persisted or were arising, in the terrain between Greece and India" (p. 395). However, Keats's ambivalence about gender and racial politics, the dreamy quality of the poem and its narrative structure complicate the issue of orientalism in the poem. 
"Resign'd" (“Endymion”, IV. 872) and "bent by circumstances" (“Endymion”, IV. 873), Endymion finds himself displaced, wandering in an alien environment far from his "dear native land" ("Endymion", IV. 31). Roving in the dark forest, haunted by nostalgia of the "wild" ("Endymion", IV. 8) regions of his country, he suddenly confronts an "inhuman beauty" (Said, 1978, p. 167). "Alone and in distress" ("Endymion", IV. 55), the Indian maid seems just another abstract entity in the mythical world of Endymion. Endymion's disturbance at sighting the Indian maid, described with "a revealingly fraught use of catalogue" (Hamilton, 1992, p.25), recalls Keats's 'On Seeing the Elgin Marbles' where "unexpectedly, seeing the marbles turns out to be a distressing experience" (Hamilton, 1992, p. 27). Gazing from "thorny-green entanglement/ of underwood" ("Endymion”, IV. 41-42), Endymion sees a "delicious lady" ("Endymion", IV. 441) helplessly looking for assistance. Abstracted beyond recognition, vulnerable to "orientalist scrutiny" and "masculine gaze", the Indian maid is described in terms of her "curls of glossy jet" ("Endymion", IV. 60) and her "dark eyes" ("Endymion", IV. 505). Since she is reduced to a mere abstraction, one cannot even imagine her appearance. Staring at her, the masculine gaze can only catch "her gentle bosom heav[ing] tumultuously" ("Endymion", IV. 100) or her soft hand and is surprised that he is "so near" ("Endymion", IV. 317). She does not appear as a presence; she more seems like "an archetypal figure" (Said, 1978, p. 119). Exotically beautiful, the Indian maid is also represented as the typical oriental woman. "A poor lonely maid" ("Endymion", IV. 287), the girl has been "in search of pleasure throughout every clime" (“Endymion”, IV. 275). Early in the poem, the girl speaks thus:

"Is no one near to help me? No fair dawn

Of life from charitable voice? No sweet saying

To set my dull and sadden'd spirit playing?

No hand to toy with mine? No lips so sweet

That I may worship them? No eyelids meet

To twinkle on my bosom? No one dies

Before me, till from these enslaving eyes

Redemption sparkles! - I am sad and lost." ("Endymion”, IV. 44-51)

Titillating, passive and pleasure-seeking, the girl embodies the oriental motifs of sensuality and ensnaring lure. Therefore, the "voluptuous" ("Endymion", IV. 759) Endymion finds himself "caught in the trammels of perverse deliciousness" ( "Endymion", IV. 761). Represented as "sad and lost" ( "Endymion”, IV. 51), the Indian maid figures the Orient's passivity and submission besides the fact that the figuration of India, "the spirit of the conquered nation," as a desolate and abandoned young woman is one instance of adherence to the orientalist motifs of the 1810s (Butler, 1994, p. 419). The West's dominance is wishfully achieved "with very little resistance on the Orient's part" (Said, 1978, p. 7). Endymion sees himself instantly in possession of the maid. She becomes "my sweetest Indian" ( "Endymion”, IV. 648), "my Indian bliss" ("Endymion", IV. 663) or simply "sweetest Indian" ("Endymion”, IV. 910). Endymion can be a representation of, to use Edward Said's words, "'the hegemonism of possessing minorities'" (1978, p. 98). Possessed and defined oppositionally, the Indian maid's individuality is done with for the sake of the poet's self-realization. In line with all the "essentially private fantas [ies]" of his co-Romantics, Keats "bolster[s] Western superiority by providing an Eastern alter ego- weak, sensuous, servile, effeminate- where the West is strong, free and manly" (Butler, 1994, p. 397). Equally important is the mythological Bacchus here. Confronting the Indian maid "gives the poet an opportunity, of which he takes a noble advantage, of describing a procession of Bacchus." (Bailey, 1818, p. 82) Associated with western mythology, Bacchus "wandered throughout Egypt and Syria. From there he went up the Asian coast until he reached Phrygia, ... Cured of his madness, Dionysus went to Thrace ... From Thrace he went to India, which he conquered by force of arms (he had an army with him) and also by enchantments and mystic powers." (Grimal, 1990, p. 128) Bacchus, as represented in the poem, has "plump white arms, and shoulders enough white" ( "Endymion", IV. 213); he is "A conquering" ( "Endymion", IV. 223) hero who has travelled "with Asian elephants" ( "Endymion", IV. 242) "through kingdoms wide" ("Endymion", IV. 225). Symbolizing "the period's hunger for essentialist universal knowledge,” (Butler, 1994, p.398) Bacchus and his followers traverse

with song and dance,

With zebras striped, and sleek Arabians' prance,

Web-footed alligators, crocodiles,

Bearing upon their scaly backs, in files,

Plump infant laughers mimicking the coil

Of seamen, and stout galley-rowers' toil:

With toying oars and silken sails they glide,

Nor care for wind and tide. ("Endymion", IV. 243-250)

Not satisfied with merely evoking the exoticism of the images associated with Bacchus, "the archetypal founder of empires," (Butler, 1994, p. 423) Keats further 'orientalizes' this figure in the speech of the Indian maid herself:

"I saw Osirian Egypt kneel adown

Before the vine-wreath crown!

I saw parch'd Abyssinia rouse and sing

To the silver cymbals' ring!

I saw the whelming vintage hotly pierce 
Old Tartary the fierce!

The kings of Inde their jewel-sceptres vail,

And from their treasures scatter pearled hail;

Great Brahma from his mystic heaven groans,

And all his priesthood moans;

Before young Bacchus' eye-wink turning pale. ("Endymion”, IV. 257-267)

The exoticized, sensualized - "Orientalized," in Said's terms (1978, p. 3) - Orient willingly submits to the god of Western mythology. Also, Endymion's encounter with the Indian maid in an alien environment and the evocation of the military conquest of the Bacchus achieve a double significance through the allegorical structure of the poem. Keats's allegorical Endymion bespeaks its writer's wish for participation in the period's orientalism which was more politically oriented. Butler (1994, p. 399) expatiates on the importance of the emergence of this poetic form (the long allegorical poem) thus:

"Poets, travel-writers, novelists undoubtedly belong in a discourse through which the British teach themselves about India and acquire the national will to be there. The long allegorical poem, creating an imaginary empire in the East, is a form which comes into existence in the1790s [...] The form coincides with Britain's main period of Indian wars of conquest, effectively taking off in the decade 1795-1805, when the East India Company's bridgeheads in Bengal, Madras and Bombay were transformed into what became by 1807 an empire engorging most of the subcontinent south of the Himalayas."

However, the poem's ambiguity undermines the attempt to simplify its orientalism. As Marjorie Levinson has argued (1988), Keats uses his cultural marginality to undercut authoritarian values. In fact, Keats is a figure that invokes the characteristic ambivalence of "margins of a nation-space" (Bhabha, 1990, p. 4). It is helpful to recall Keats's oeuvre as one marked by imaginatively-created worlds, spaces, peopled with figures of another kind of reality. Through imagination, Keats creates the aesthetic as the sphere in which he can examine "the Wittgensteinian 'point' or teleology of any discourse," "a sphere which must be re-occupied for any revolutionary orientation of society to take place" (Hamilton, 1992, p.12). For Keats, imagination is a "defensive agency" against a reality so harsh to his identity. Stamping his subject matter and his "aggressively literary style" (Levinson, 1988, p. 286), Keats's imagination is usually engaged in a profound crisis of consciousness and personality.

Believing that his fate is "all cast" ( "Endymion", IV. 901) and that he is "cruelly wrong'd" ("Endymion”, IV. 748), Endymion considers himself borne to "dangerous winds" ("Endymion", IV. 616). This "warm mountaineer" ( "Endymion", IV. 54) whose "wandering" ( "Endymion”, IV. 766) is characterized by a sense of homelessness sighs for "but one short hour/ Of native air - let me but die at home." ("Endymion”, IV. 37) Regarding himself as an outcast, Keats tries to build a sense of home in the vast nature sheltering his dreams, memories and unconscious desires. Not feeling at home in the "wolfish" ( "Endymion", IV. 5) England, he cannot help feeling himself identified with the figure of the Other in his safe poetic space. "Unseen, alone" ("Endymion", IV. 350) and "with a warm tremble of a devout kiss" ("Endymion", IV. 744), Endymion "murder [s] half [his] soul" ("Endymion”, IV. 309) to "kneel" and "adore" ( "Endymion", IV. 302) the Indian maid. "Bending" ("Endymion", IV. 712) to dear love of the Indian maid, he forgets the western Cynthia in order to "embrace" ("Endymion", IV. 759) a love more heavenly. He melts so much in the Other that the Indian maid and Cynthia seem to have changed places: " Why does his lady smile, pleasing her eye/ With all his sorrowing? He sees her not" ( "Endymion”, IV. 798-799). Actually, it was Endymion who was pleased by gazing at the sorrowful Indian maid when he confronted her. Aestheticizing and spiritualizing the love for the Indian maid, he is well aware that such love cannot happen on earth. They must be united "so aloof/ up in the winds" where they can be "witless of their doom" ( "Endymion", IV. 490-492). Sexually threatening and ensnaring, the oriental woman is usually represented as a destructive figure, emasculating the western self. Endymion is sure that "some fearful end must be: where, where is it?" ("Endymion”, IV. 478) since he has been:

Presumptuous against love, against the sky,

Against all elements, against the tie

Of mortals each to each, against the blooms

Of flowers, rush of rivers, and the tombs

Of heroes gone! Against his proper glory

Has my own soul conspired: so my story

Will I to children utter, and repent. ("Endymion", IV. 639-645)

So he repents and finding himself once more associated with the Other, he tries to reaffirm his identity. A shared feature among Romantics, such "internalization" of orientalist discourse, "a power structure showing on its own terms the mechanisms by which the prohibitions necessary for acceptance into the symbolic order are enforced," (Hamilton, 1992, p. 15) assumes a considerable importance for Keats and especially for Endymion, given the hopes with which it was written. In fact, the poet has only temporarily lost himself in another object: "Do gently murder half my soul and I/ Shall feel the other half so utterly! - " (Endymion”, IV. 309-310). As Richardson (2001) puts it, although Keats usually "voices the desire to transcend the limitations of earthly existence, such moments are typically followed by the recognition - at once chastening and unexpectedly heartening - that the end of sense experience would mean an end to imaginative life. In Endymion this is called the "journey homeward to habitual self" (p. 234). Therefore, after the 
implied sexual union with the Indian maid on the horses in the region of the "Sleep" ("Endymion", IV. 370), he again steps back from her in the symbolic scene of her evaporation. Although sexuality can signify social regeneration, a telling gesture recurring in Keats's poetry, desire, glamorized, for an oriental Other can violate Keats's search for a masculine autonomy. Striving for self-realization but disconnected from the Other, Endymion becomes a youth of no character: "What is this soul then? Whence/ Came it? It does not seem my own, and I/ Have no self-passion or identity" ("Endymion", IV. 475-477). That's why the "common impression" of critics in 1884 was "that the author of Endymion was a feeble creature, seriously lacking in self-control" (Najarian, 2002, p.30). Formerly trying to shape his identity in relation to Cynthia, a symbolic embodiment of power who had acted more like a deferred presence, he had cancelled that would-be identity after taking the Indian maid as the alternate Other. Ideologically and psychologically denied the identification with the Indian maid, once more he expresses being "not so much as Other ... but as 'nothing' "(Levinson, 1988, p. 287). "Agree [ing] with de Man that Endymion privileges sympathy," Najarian (2002, p. 165) sums the situation thus:

Sensuous love has a radiating effect. It is easily redistributed among others in the form of sympathy, which de Man defines as "a forgetting of the self for the sake of others, especially when the other is in a state of suffering." As the self is forgotten or abandoned at moments of sympathy with others, these moments can be metaphorically expressed as trance or sleep. Sleep aptly figures the loss of self necessary to true sympathy. According to de Man, this sympathy with others has a negative side; it shelters one from knowledge of the self.

Endymion's resolve to become a hermit does not please him either. Eros is Keats's only way of connecting with the reality slighting him (Cox, 2001, p. 58). Hermit's living in seclusion does not match Keats's already marginal life.

Pained and hot

His eyes went after them, until they got

Near to a cypress grove, whose deadly maw,

In one swift moment, would what then he saw

Engulph for ever. "Stay!" he cried, "ah, stay!

Turn, damsels! hist! one word I have to say.

Sweet Indian, I would see thee once again. ( "Endymion", IV. 904-910)

As Edward Said notes, "a sense of irreducible distance separat[es] white from colored" (1978, p. 228). The Indian maid must be transformed so that Keats's spiritual love for her becomes culturally sanctioned. "Keats, in so far as he is seen as creator and consumer of such orientalist constructions, is thus viewed as distancing himself from or, at most, aestheticizing the realities of oppression and victimization" (Wassil, 2000, p. 419).

into her face there came

Light, as reflected from a silver flame:

Her long black hair swell'd ampler, in display

Full golden; in her eyes a brighter day

Dawn'd blue and full of love. (“Endymion", IV. 982-986)

Westernized, the Indian maid achieves, to use another Saidian phrase, "superior ontological status" (Said, 1978, p. 226). Endymion explains the occurrence thus to the maid:"'twas fit that from this mortal state/ Thou shouldst, my love, by some unlook'd for change/ Be spiritualiz'd" (“Endymion”, IV. 991-993). On this Bailey (1818), partly responsible for Blackwood's attack on the poem, noted that: "The catastrophe of the poem is this young Indian being changed into Diana" (p. 82). But he reckoned it to be an "unconscious coincidence"(Ibid). Rather, the Indian maid's metamorphosis indicates Keats inability to cope with the forces of "orientalist discourse". It is helpful to recall that the portrayal of the Indian maid, England's Orient, takes the course of her psychological and racial reduction followed by spiritualization of the love for her. "In a negative reformation, the creation of identity", as Wassil (2000) aptly maintains, "may signal the repression of otherness, but such an act of repression already signals the development of a more complex structure within that identity" (p. 423). Cutting himself off from the world of political tangibilities and, as a result, uncomfortable in the role thus fashioned for himself, Keats once more says adieu to the deceiving fancy of being tolled back from the realm of retreat to his "sole self" ("Nightingale", 72), to feel like participating in a masculinity defined by its unrestricted control over the feminine other. Therefore, Keats' equivocation in Endymion seems in keeping with his ambivalent gender politics, his social marginality added to the cultural pressure of "orientalist discourse". "His literary output is thus seen as representative of what he failed to control, what lies outside the text in the abstract social forces which shape literature; thus Keats and the poetry become a 'system of wishes and resistances,' a 'dynamic reflection of social configurations" (Wassil, 2000, p. 424). The union of Endymion and Diana, also, as Kandel (2001) quotes de Man, has "“a communal spirit of friendship with social and political overtones; something of the spirit of the French Revolution"" (p. 11).

Also indicative of Keats's poetry is a subtle stylistic and textual ambiguity. Endymion's ambiguities were mostly considered by his contemporaries as poetical immaturity. Even its orientalism, Leask believes, is "primarily a question of style" (as cited in Wassil, 2000, p.419). Lockhart (1818, p. 100) snorted:

As for Mr Keats' Endymion, it has just as much to do with Greece as it has with 'old Tartary the fierce; no man, whose mind has ever been imbued with the smallest knowledge or feeling of classical poetry or classical history, could have stooped to profane and vulgarise every association in the manner which has been adopted by this 'son of promise.' 
In an unsigned review, 'Endymion, a monstrously droll poem' (1818), the critic's impression was that: "Somebody sings a very pitiful song to sorrow; and somebody else gets upon horseback with Endymion" (p. 92). Reference to this poem in Keats oeuvre has usually been dismissive and regretful. Although "both detractors and supporters [have] remained caught in the poem's image-making machinery" (Swann, 2001, p. 20), it has evoked less excitement than other poems of Keats. Frequent distracting digressions, a non-traceable point of view and vacillating tone, sometimes obscuring the referent of pronouns beyond plausibility, seem some of its poetical drawbacks. But what has remained less acknowledged is the cause of these defects. What cannot be neglected in a careful analysis of the poem is its dreamy quality. "The occasion of Endymion," as Kucich (2001) explains, through Keats's "attention to The Canterbury Tales and Troilus and Criseyde involved Chaucer's narrative powers and, particularly, his evocations of psychic interiority and deep pathos" (p. 191). In his struggle for identity, the poet journeys through "that deep den of all" ("Endymion”, IV. 225). The poem seems to be a psychological dramatization of the poet's effort to reintegrate his split subjectivity, an opportunity to be reunited with his anima maid to achieve a full sense of his personality. In his specific way of dealing with "Spenserian material," Keats "unfold[s] the psychodynamics implicit in the allegory - of imaginative idealism pressured by a sense of reality - and leave the conflict unresolved, or resistant to any clear moral interpretation" (Kucich, 2001, Ibid). Plunging into his labyrinthine unconscious, Endymion is haunted by "cloudy phantasms" ("Endymion”, IV. 651) and "airy voices" ("Endymion”, IV. 654) cheating him on his way. Tropes of darkness, sexuality and desire further reinforce the uncanny quality of the poetic space. The logic of these "dark regions" ("Endymion", IV. 516), "the proper home/ of every ill" ("Endymion", IV. 521-522), is that of a sudden surge of rationally inexplicable figures; they have the mysterious force of figures from the unconscious. "So from the turf outsprang two steeds jet-black, / Each with large dark blue wings upon his back" (“Endymion”, IV. 343-344). In addition to the uncanny horses exciting fear, the Indian maid's vanishing and reappearance conform to the "inner repetition-compulsion" principle surrounding whatever which is perceived as uncanny (Freud as cited in Rivkin, 2000, p. 164). Such "gothicization", it is important to mention in passing, is another instant of Keats's observance of the orientalist motifs of the period, this time of Southey's orientalizing "narrative paradigms" back in the 1800s (Butler, 1994, p. 415). Probing his unconscious, Endymion is left with the impression of a spurious dream. Tangled "in wonderment" (“Endymion”, IV. 1003), he complains that: "I have clung/To nothing, lov'd a nothing, nothing seen/ Or felt but a great dream!" ("Endymion”, IV. 636-638) And dreams, "the bearer of the subject's desire," (Lacan, 1981, p. 55) are the "realization of a desire" (Lacan, 1981, p. 57). Keats's oeuvre, as Wassil (2000) writes, is one marked by "unavailability" of female figures "and the frustrated marriages associated with them" (p. 428). In fact, in returning to his poem, Keats returns to a very personal and haunting memory: the love of Fanny Brawne. Endymion is Keats's memoir, his recollection of his separation from Fanny. As "a common structure in Keats," (Najarian, 2002, p. 111) Endymion's quiet "bower" of its opening lines, "are self created spaces [...] in the memories and experiences that the mind makes for itself" (Najarian, 2002, p. 36). Kandel (2001) also seems aware of the implicit Fanny when he argues that the poetic union of Endymion and Diana is "revolutionary: wrathfully breaking the Jovian edict that would keep Cynthia eternally chaste, this 'Poet' releases not just these two but liberates a host of lovers from their states of isolation, oppression, or the repression that renders them the 'languid sick' "(p. 10). The dream of his reunion is thinkable only with the silent, "meek" ("Endymion”, IV. 73), and the exotically beautiful Indian maid, an oriental Other of easy availability. Denied gratification of Fanny's love, Keats employs the serviceable black body of the Indian maid for his own purpose: the projection of his sexual desires. "Keats's sensually opulent style" was, as Vendler (2007, p. 27) puts it, a development "for the happier embraces, both spiritual and physical, of Endymion" with Endymion "placed in a dream state even as the speaker wishes for a similar state of liminal, eternal sexual pleasure" (Najarian, 2002, p. 35). Therefore, although he is unconsciously satisfied, Keats aestheticizing the love for the Indian maid, as his surrogate Fanny is still ideologically problematic. Consequently, his urgent need to preserve his reunion makes him move beyond the rules of plausibility. The narrative once more strays from its credibility when the Indian maid is suddenly transformed into a golden-haired and blue-eyed girl. Since he is moved by his irrepressible unconscious impulses, Keats's poetry has become loose in plot construction. In emplotting "the distracting presence of another temporality" (Bhabha, 1990, p. 295), Keats becomes aware of "the unheimlich terror of the space or the race of the Other" (Bhabha, 1990, p. 2) shaking the pillars of his narrative structure. To save his poem, after the flight on the horses with the "purple mist around them" (“Endymion”, IV. 367) is over, "the dark-eyed stranger" ( "Endymion”, IV. 977) must instantly fade away. In Orientalism, Edward Said (1978, p. 20) observes that:

Everyone who writes about the Orient must locate himself vis-a-vis the Orient; translated into his text, this location includes the kind of narrative voice he adopts, the type of structure he builds, the kinds of images, the themes, motifs that circulate in his text — all of which add up to deliberate ways of addressing the reader, containing Orient, and finally, representing it or speaking in its behalf.

To contain and manipulate this fascinating but disturbing Other, Keats controls the point of view of his narrative especially after Endymion's partial identification with the Indian maid. Although, at times, the dreamy quality of the poem and Keats's ambivalent politics obfuscate the point of view beyond recognition, generally it fluctuates between the dramatic and limited omniscient point of view restricted to Endymion's thought and feelings. What the Indian maid herself tells "will not undo that somewhere else she is told." (Lyotard, as cited in Bhabha, 1990, p. 301) Accordingly, rendered voiceless after her early exclamation of "woe" (“Endymion”, IV. 30) and "horror" (“Endymion”, IV. 468), the 
Indian maid becomes a speechless object, she falls into an eternal sleep, only to evaporate into non-existence. In fact, following their necessary initial dialogue the focus of the narrative is almost exclusively on Endymion. The narrative voice can then freely shift between the narrator and Endymion. Centered on Endymion, the point of view reveals Keats's unconscious anxiety for his attachment to an oriental Other.

Ah, what perplexity! Ah, well a day!

So fond, so beauteous was his bed-fellow,

He could not help but kiss her: then he grew

Awhile forgetful of all beauty save

Young Phoebe's, golden hair'd; and so 'gan crave

Forgiveness: yet he turn'd once more to look

At the sweet sleeper, - all his soul was shook,-

She press'd his hand in slumber; so once more

He could not help but kiss her and adore.

At this the shadow wept, melting away. ("Endymion”, IV. 447-456)

Endymion's wavering desire for the easily accessible Indian maid and the golden-haired Diana, supposedly resembling his Fanny, is, to use Edward Said's words, "the vacillation between the familiar and the alien" (1978, p. 72). Even Keats's poem is not fair to him. Silencing the oriental Other, Keats betrays his Endymion's spiritualization of his love for the Indian maid and thus foreshadows his second relieving spiritualization. Consequently, the poem becomes a failure on another level. Early in his career, Keats had not yet learned how to dominate the feminine Other, the way he "obliterates" (Steyaert, 1996, para. 3) Psyche's identity, for instance, for the sake of a true masculinity. Choosing an oriental Other for easy gratification of a love denied him, Keats exemplifies the influence of traditional oriental dogmas on his imagination joining his cultural marginality.

\section{REFERENCES}

[1] A monstrously droll poem. (1818). In G. M. Matthews (Ed.), John Keats: The Critical Heritage (pp. 88-93). London: Routledge

[2] Abrams, M. H., et al. (Eds.). (1987). The Norton Anthology of English Literature (6 ${ }^{\text {th }}$ ed., Vol. 3). New York: W.W. Norton \& Company.

[3] Bailey, Benjamin. (1818). Bailey advertises Endymion. In G. M. Matthews (Ed.), John Keats: The Critical Heritage (pp. 79-83). London: Routledge.

[4] Bhabha, Homi K. (Ed.). (1990). Nation and Narration. London: Routledge.

[5] Butler, Marilyn. (1994). Orientalism. In David B. Price (Ed.), The Penguin History of English Literature: Vol. V. The Romantic Period (pp.395-447). London: Penguin Books.

[6] Cox, Jeffrey N. (2001). "Lamia, Isabella, and The Eve of St. Agnes: Eros and 'romance'”. In Susan J. Wolfson (Ed.), The Cambridge Companion to Keats. Cambridge: Cambridge University Press.

[7] Grimal, Pierre. (1990). The concise Dictionary of Classical Mythology. England: Basil Blackwell.

[8] Hamilton, Paul. (1992). 'A Shadow of a Magnitude': The Dialectic of Romantic Aesthetics. In Stephen Copley \& John Whale (Eds.), Beyond Romanticism: New Approaches to Texts and Context of 1780-1832 (pp. 11-31). London: Routledge.

[9] Kandl, John. (2001). "The politics of Keats's early poetry: 'Delight' with 'liberty”. In Susan J. Wolfson (Ed.), The Cambridge Companion to Keats. Cambridge: Cambridge University Press.

[10] Keats, John."Endymion. Book IV." 5 July 2011. Retrieved from http://www.bartleby.com.

[11] Keats, John. (1818). Letters and Prefaces. In G. M. Matthews (Ed.), John Keats: The Critical Heritage (pp. 72-75). London: Routledge.

[12] Kucich, Greg. (2001). "Keats and English poetry". In Susan J. Wolfson (Ed.), The Cambridge Companion to Keats. Cambridge: Cambridge University Press.

[13] Lacan, Jacques. (1981). The Four Fundamental Concept of Psychoanalysis (A. Sheridan, Trans.). New York: W. W. Norton \& Company.

[14] Levinson, Marjorie. (1988). "Keats's Life of Allegory: The Origins of a Style”. In Uttara Natarajan (Ed.), The Romantic Poets: A Guide to Criticism. Blackwell Publishing.

[15] Lockhart, John G. (1818). Lockhart's attack in Blackwood's. In G. M. Matthews (Ed.), John Keats: The Critical Heritage (pp. 94-107). London: Routledge.

[16] Mellor, Ann K. (2001). "Keats and the complexities of gender". In Susan J. Wolfson (Ed.), The Cambridge Companion to Keats. Cambridge: Cambridge University Press.

[17] Najarian, James. (2002). Victorian Keats: manliness, sexuality, and desire. New York: Palgrave Macmillan.

[18] Richardson, Alan. (2001). "Keats and Romantic science: Writing the body". In Susan J. Wolfson (Ed.), The Cambridge Companion to Keats. Cambridge: Cambridge University Press.

[19] Rivkin, J., \& Ryan, M. (Eds.). (2000). Literary Theory: An Anthology. Blackwell Publishers.

[20] Said, Edward W. (1978). Orientalism. New York: Vintage Books.

[21] Steyaert, Kris. "Poetry as Enforcement: Conquering the Muse in Keats's 'Ode to Psyche'." Romanticism On the Net 1 (February 1996). Retrieved from http://users.ox.ac.uk/ scat0385/ psyche.html.

[22] Swann, Karen. (2001). "Endymion's beautiful dreamers". In Susan J. Wolfson (Ed.), The Cambridge Companion to Keats. Cambridge: Cambridge University Press.

[23] Vendler, Helen. (2007). "Tuneless Numbers: The Ode to Psyche". In Harold Bloom (Ed.), Bloom's Modern Critical Views: John Keats-Updated Edition. New York: Infobase Publishing. 
[24] Wassil, Gregory. (2000). Keats's Orientalism. Studies in Romanticism, 39, 3. 419-447.

Hossein Pirnajmuddin, is an Assistant Professor of English Literature at University of Isfahan, Iran, where he has taught since the completion of his $\mathrm{PhD}$ at University of Birmingham, UK, in 2002. His interests include Renaissance literature, colonial and postcolonial theory, postmodern fiction and translation studies.

Parisa Shiran, born in Isfahan, Iran. BA in English literature from University of Isfahan 2010. MA student of English literature at University of Isfahan. As a student of English literature, she is now writing her thesis on T. S. Eliot's Four Quartets using Derrida's deconstruction. Her main foci are not only deconstruction but also Wittgensteinian linguistics, poststructuralist literary theory and modernist poetry. 